\title{
Neutral metalloproteases and age related changes in human articular cartilage
}

\author{
JOHANNE MARTEL-PELLETIER AND JEAN-PIERRE PELLETIER \\ From the Department of Medicine, University of Montreal, Notre-Dame Hospital Research Center, Montreal, \\ Canada
}

SUMmARY A decrease in proteoglycan $(\mathrm{Pg})$ content and disturbances in the collagen network have been reported in aging cartilage. This study aims to determine whether these changes are associated with proteolytic enzymes such as neutral metalloproteases. Eighty lateral tibial plateaus were collected from subjects after death. The age, topographical area, and lesion severity (macroscopic grading) of each specimen were noted and the effects of neutral metallo-Pg-degrading and collagenolytic enzymes on these specimens were compared. The specimens were divided into two age groups: 20-50 years (group 1) and greater than 50 years (group 2). They were selected from both weight bearing and non-weight bearing areas. In some cartilage tissues the superficial layer was separated from the deep zone. Our data for the two neutral metalloenzymes examined showed: $(a)$ no correlation between enzyme activity and age when the specimens were of the same grade and $(b)$ a statistically significant rise in the enzyme levels of the older specimens, which increased as the lesions progressed. Neutral metallo-Pgdegrading enzyme activity was higher in non-weight bearing areas than in weight bearing areas, and this reached a statistical difference in the older cartilage with advanced lesions. The Pg-degrading enzyme activity was raised in the superficial layers of damaged cartilage tissue. Our data suggest that neutral metalloproteases are closely associated with the appearance and progression of the changes seen in aging cartilage.

Degenerative changes and osteoarthritis of articular cartilage increase with age, yet the precise relation between age and osteoarthritis remains unknown. Understanding the metabolic changes that occur in the articular cartilage may help to delineate the processes taking place during aging or osteoarthritis.

The physical properties of cartilage are products of the interaction between collagen and proteoglycan $(\mathrm{Pg})$ macromolecules within the extracellular matrix. The collagen fibre network and Pg structure and composition have been shown to alter with age. ${ }^{1-7}$ These changes also vary according to the depth of the articular cartilage. Other studies have emphasised the qualitative and quantitative variations in Pg macromolecules. ${ }^{-11}$ Some of the structural and biochemical changes in the matrix of aged cartilage may be due to proteolysis. ${ }^{412} 13$ Recent studies from our laboratory have demonstrated the

Accepted for publication 17 December 1986.

Correspondence to Dr Johanne Martel-Pelletier, Unité des maladies rhumatismales, Hôpital Notre-Dame, 1560 est, rue Sherbrooke. Montréal, Québec H2L 4K8, Canada. role of neutral metalloproteases in the breakdown of the osteoarthritic cartilage matrix. ${ }^{14-17}$ This breakdown was associated with significant increases in the levels of both neutral metallocollagenolytic and Pg-degrading enzymes.

Thus it would be of interest to determine whether the cartilage lesions of aging are related to changes in enzyme activity within articular cartilage. For this purpose we have investigated neutral metallocollagenolytic and Pg-degrading enzyme activities in specimens of cartilage grouped according to age. The morphology and topography of the cartilage were also taken into consideration.

\section{Materials and methods}

SPECIMEN SELECTION

Eighty postmortem tibial plateau specimens were obtained within 12 hours of death from individuals with an age range of $20-85$ years. None had shown any clinical evidence of arthritic disease nor had received any chemotherapeutic agents. ${ }^{18}$ Before the 
dissection the quality of the articular surface was graded by Meachim's Indian ink staining methods. ${ }^{19}$ Cartilage samples with no evidence of surface disruption were designated grade 0 ; those with minimal surface disruption were designated grade 1 ; those with fibrillations in the superficial layer only were designated grade 2; and those with erosions or the most severe lesions were designated grade 3 . Each grade was divided into two groups according to age: $20-50$ years, and greater than 50 years.

The specimens were selected from a weight bearing area, or central region exposed to direct contact, and a non-weight bearing area, or peripheral region covered by the meniscus. For some tibial plateaus the tissue of the entire cartilage was separated into layers: an upper layer of approximately one third the total thickness of the cartilage and a deeper layer consisting of the remainder of the cartilage to the subchondral bone. The deep zone of the articular cartilage was further separated from the calcified tissue.

\section{ENZYME AS SA YS}

The neutral metalloprotease assays, i.e., collagenolytic and Pg-degrading enzyme activity, have been described elsewhere. ${ }^{14}{ }^{15}$ Each assay was performed on separate homogenates and subjected to different experimental procedures. The micro믐 assays were based on the digestion of an endogenous substrate.

Briefly, the collagenolytic enzyme activity was determined after homogenisation of the tissue in TRIS (trometamol) buffer (50 mM TRIS- $\mathrm{HCl}, 15 \mathrm{~F}$. $\mathrm{mM} \mathrm{NaCl}, 10 \mathrm{mM} \mathrm{CaCl}_{2}, 0.02 \%$ (w/v) $\mathrm{NaN}_{3}, 40 \mu$ 原 $(40 \mathrm{mg} / \mathrm{ml})$ of gentamicin), $\mathrm{pH} 7 \cdot 4$, followed b\% incubation $\left(18 \mathrm{~h}, 37^{\circ} \mathrm{C}\right)$ and centrifugation $(20000 \mathrm{~g}$ $\left.45 \mathrm{~min}, 4^{\circ} \mathrm{C}\right)$. After hydrolysis, the amount ${ }^{\circ}$ hydroxyproline was measured in both the super $=$ natant and the pellet. ${ }^{20}$ The enzyme activity was estimated by the release of soluble fragments containing hydroxyproline and expressed as the percentage of hydroxyproline released.

The Pg-degrading enzyme activity was deterir mined ${ }^{15}$ after homogenisation in TRIS buffer $(50 \mathrm{mN}$ TRIS- $\mathrm{HCl}, 150 \mathrm{mM} \mathrm{NaCl}, 10 \mathrm{mM} \mathrm{CaCl} 2,80 \mu \mathrm{g}$ $(40 \mathrm{mg} / \mathrm{ml})$ of gentamicin), $\mathrm{pH} \mathrm{7.4}$, followed by incubation $\left(42 \mathrm{~h}, 37^{\circ} \mathrm{C}\right)$ and centrifugation $(12000 \stackrel{\vec{g}}{\overrightarrow{7}}$ $\left.30 \mathrm{~min}, 4^{\circ} \mathrm{C}\right)$. The method used to measure the amount of proteoglycan released was based on the formation of a complex between proteoglycan $\$$ their digested products, and cetylpyridinium chlor ide. The digested products were then selectively released with trichloroacetic acid and measured b their uronic acid content. The enzyme activity wö

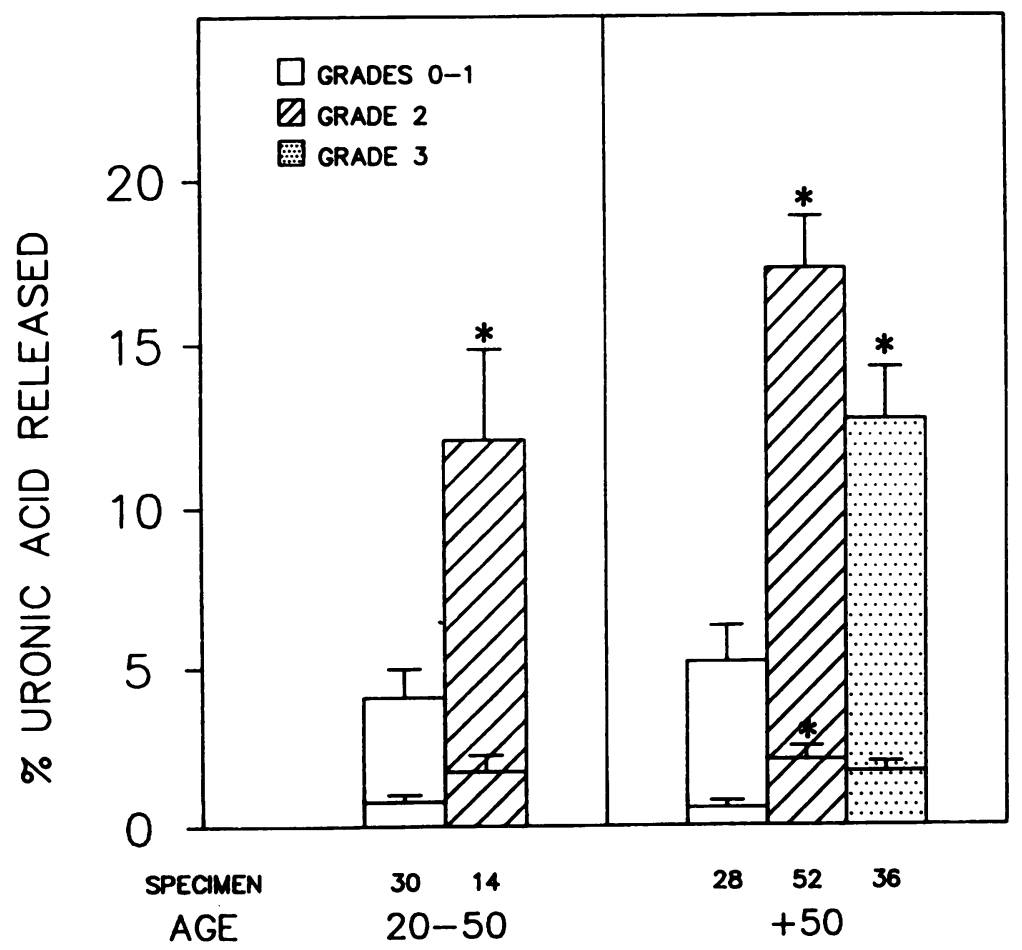

Fig. 1 Neutral metallo-Pgdegrading enzyme activity in human articular cartilage correlation with aging and severity of lesions. The assay and the calculation of the enzyme activity are described in 'Materials and methods'. The results are expressed. as mean (SEM) of the percentage of uronic acid released. The entire column represents the total enzyme 음 activity (APMA activated); the lower part of the column represents the active form of the enzyme. The analysis of variance was used for the statistical analysis. The total enzyme activities of grade 2 and grade 3 cartilages are significantly different from the activity obtained for grade $0-1$. This is true for group $1(p<0.001)$ and for group $2(p<0.001)$. The active form of group 2, grade 2 cartilage is significantly different from that of grade $0-1(p<0.02)$. 
expressed as a percentage of the uronic acid released.

Total neutral metalloproteases were measured by the digestion found in the cartilage homogenates which were incubated in the presence of $p$-aminophenylmercuric acetate $(1 \mathrm{mM})$ minus that found in those incubated with chelators $-25 \mathrm{mM}$ ethylenediaminetetra-acetate (for collagenolytic enzyme) or $5 \mathrm{mM} o$-phenanthroline (for Pg-degrading enzyme). The active enzymes were measured as the value obtained in the cartilage homogenates which were incubated alone minus that value obtained for those incubated with appropriate chelators.

\section{STATISTICAL ANALYSIS}

All results were expressed in the form of mean (SEM). Comparisons were made by the analysis of variance to determine any significance in the data.

\section{Results}

The distribution of the specimens was as follows: $(a)$ grades $0-1,15$ specimens $<50$ years $(2 \mathrm{~F} / 13 \mathrm{M})$ and 14 specimens $>50$ years $(7 \mathrm{~F} / 7 \mathrm{M}) ;(b)$ grade 2 , seven specimens $<50$ years $(2 \mathrm{~F} / 5 \mathrm{M})$ and 26 specimens $>50$ years $(5 \mathrm{~F} / 21 \mathrm{M}) ;(c)$ grade 3,18 specimens $>50$ years $(8 \mathrm{~F} / 10 \mathrm{M})$. We did not find any severe (grade 3 ) lesions in the cartilage of individuals from group 1.

Fig. 1 shows the level of total and active neutral metallo-Pg-degrading enzyme activity. In the speci- mens graded $0-1$, both age groups showed similar levels. Differences were seen when the enzyme activity of the cartilage with degenerative changes was analysed. The highest level of activity was in group 2, but this appeared to be due to lesion severity rather than to age. A threefold increase in total enzyme activity was recorded in grade 2 and 3 specimens compared with those graded $0-1$. This was true for both age groups. When the $\mathrm{Pg}$ degrading enzyme activity was compared with that of grade $0-1$ specimens it was found to increase significantly in group 1 , grade 2 specimens $(p<0 \cdot 001)$ and in group 2 , grade 2 and 3 specimens $(p<0.001)$. Interestingly, there was a decline in enzyme activity in grade 3 specimens compared with grade 2 specimens.

There was a similar trend for the active form of Pg-degrading enzymes. The changes in enzyme activity were not related to age but seemed to be related to lesion severity. Active Pg-degrading enzyme activity was enhanced in specimens with degenerative changes. In group 2 there was a statistically significant increase $(p<0.02)$ in the enzyme activity of grade 2 compared with grade $0-1$. Again, there was a decrease in activity of the active form of Pg-degrading enzymes in the most severely damaged specimens.

No clear variation of neutral metallocollagenolytic enzyme activity (Fig. 2) was found in group 1.

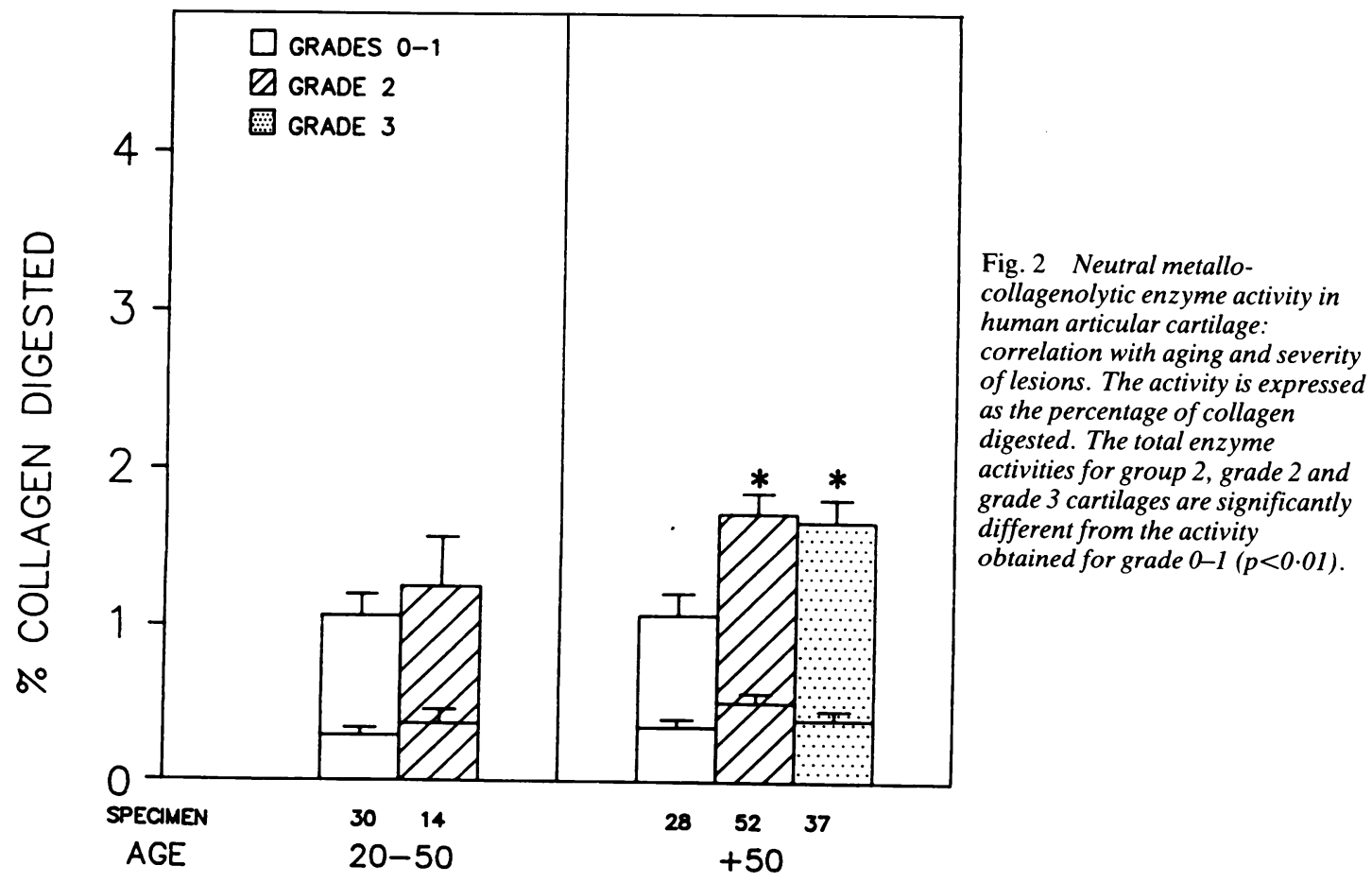




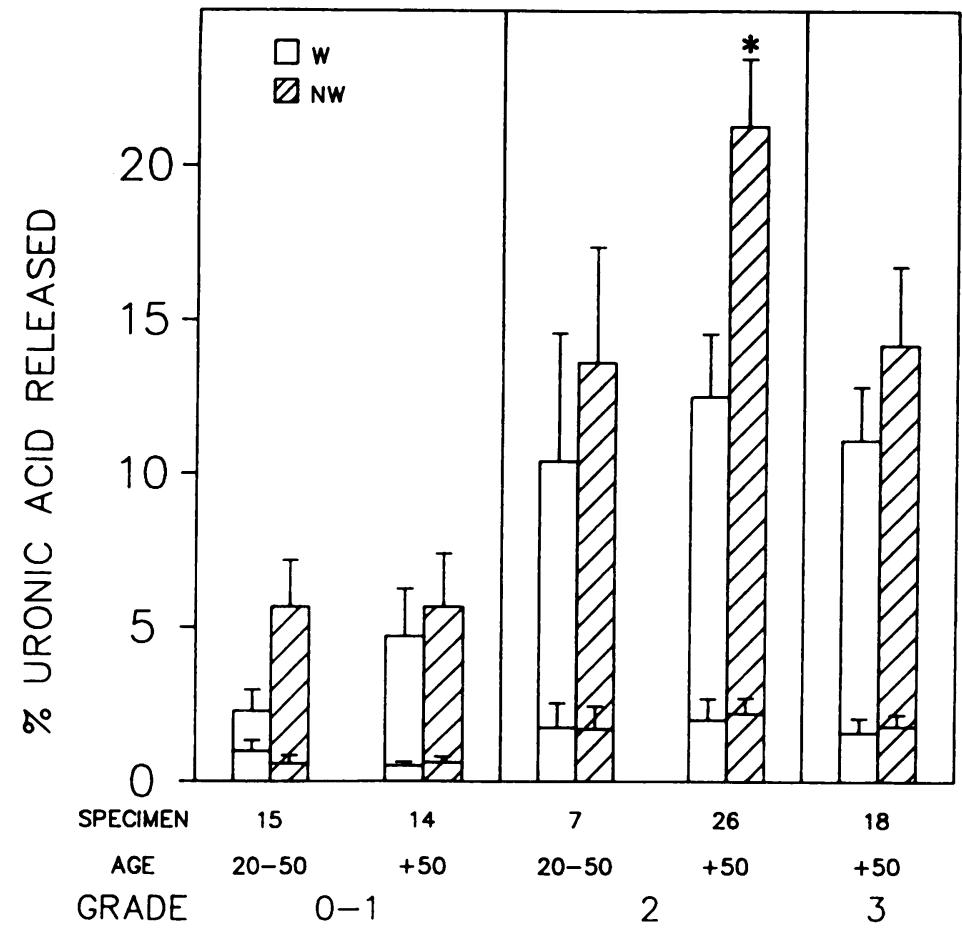

Fig. 3 Neutral metallo-Pg-degradin $\overrightarrow{8}$ enzyme activity in human articular $\overrightarrow{\vec{H}}$ cartilage: relationship between weigh bearing $(W)$ and non-weight bearingo (NW) areas on the tibial plateau.

The total enzyme activity of

? non-weight bearing areas for group $2 \mathrm{r}$ grade 2 is significantly different fromiు that of weight bearing areas $(p<0.02 \%$

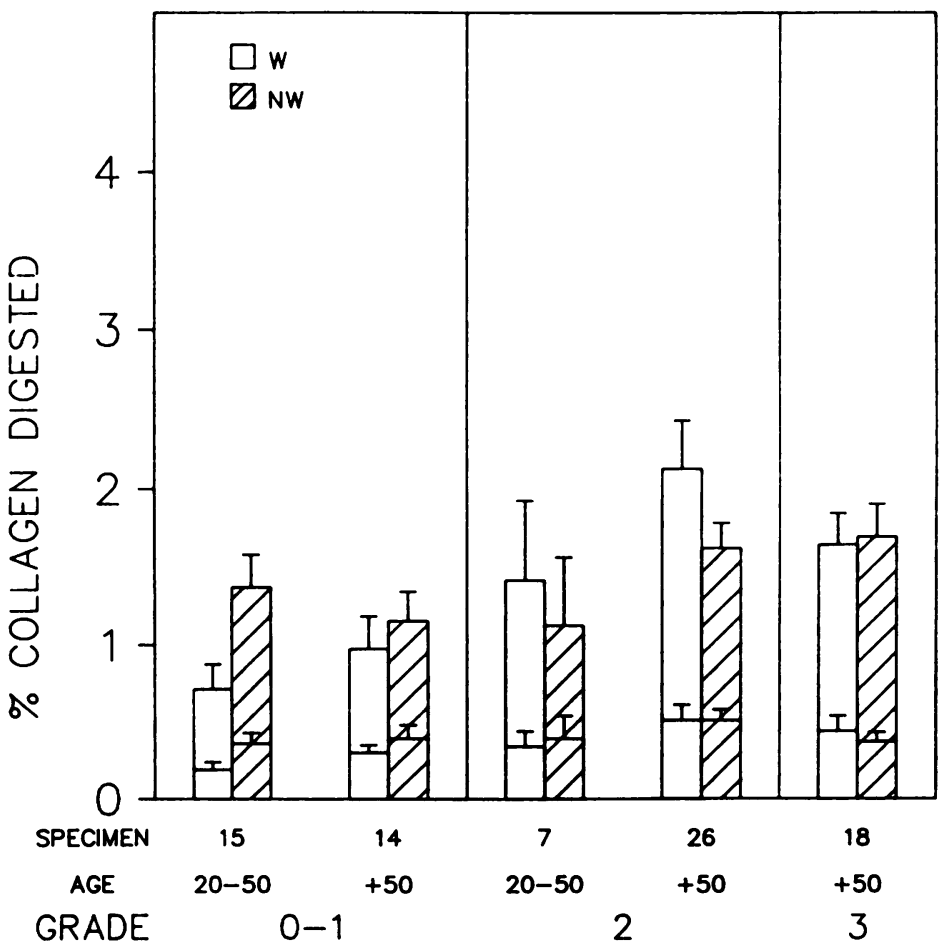

Fig. 4 Neutral metallocollagenolytiç enzyme activity in human articular cartilage: relationship between weigh? bearing $(W)$ and non-weight bearing $(N W)$ areas on the tibial plateau.

No group had any increased level of enzyme activity. 
In group 2, however, there was a higher level of enzyme as the lesions progressed. The neutral metallocollagenolytic enzyme activity was significantly higher in grade 2 and 3 specimens than in grade $0-1$ specimens $(\mathrm{p}<0 \cdot 01)$.

As shown in Fig. 2 there was no raised level of active collagenolytic enzyme in either group.

There is evidence to suggest that in cartilage from the tibial plateau the morphology of proteoglycan $^{1121}$ and collagen ${ }^{22}$ may vary according to location, and particularly if the cartilage is located in weight bearing or non-weight bearing areas.

Figs 3 and 4 illustrate the neutral metalloprotease levels in weight bearing and non-weight bearing areas of the tibial plateau. In grade $0-1$ specimens the total Pg-degrading enzyme level showed little variation with respect to age or area (Fig. 3). The total enzyme activity increased, however, as the severity of lesions progressed and was substantially greater in non-weight bearing areas. This increase was statistically significant in group 2 , grade 2 specimens $(\mathrm{p}<0.02)$.

The active form of this enzyme followed a pattern similar to that reported for the entire cartilage (Fig. 1). Levels of active Pg-degrading enzyme increased in grade 2 and 3 specimens in both weight bearing and non-weight bearing areas. There was no significant difference in enzyme levels between the two areas.

The levels of total and active collagenolytic enzyme (Fig. 4) did not change with respect to age or lesion severity in either weight bearing or non-weight bearing areas of the tibial plateau. A slight rise in total enzyme activity was recorded for grade 2 and 3 specimens.

It has been reported that the proteoglycan composition of aging articular cartilage changes in relation to the depth of the cartilage. ${ }^{8-11}$ If proteolysis were involved in this process the enzymatic pattern might very well differ according to the distance from the surface of the articular cartilage to its core. To test this hypothesis neutral metallo-Pgdegrading enzyme activity was analysed in both the superficial layer and the deep zone of the cartilage specimens.

In this series four specimens $(1 \mathrm{~F} / 3 \mathrm{M})$ graded $0-1$ belonged to group 1 and four specimens (1F/3M) graded $0-1$ belonged to group 2 . Grade 2 consisted of six specimens $(4 \mathrm{~F} / 2 \mathrm{M})$ in group 1 and 14 $(3 \mathrm{~F} / 11 \mathrm{M})$ in group 2 . Grade 3 consisted of nine specimens $(3 \mathrm{~F} / 6 \mathrm{M})$ and all were in group 2 .

Fig. 5 shows that total Pg-degrading enzyme

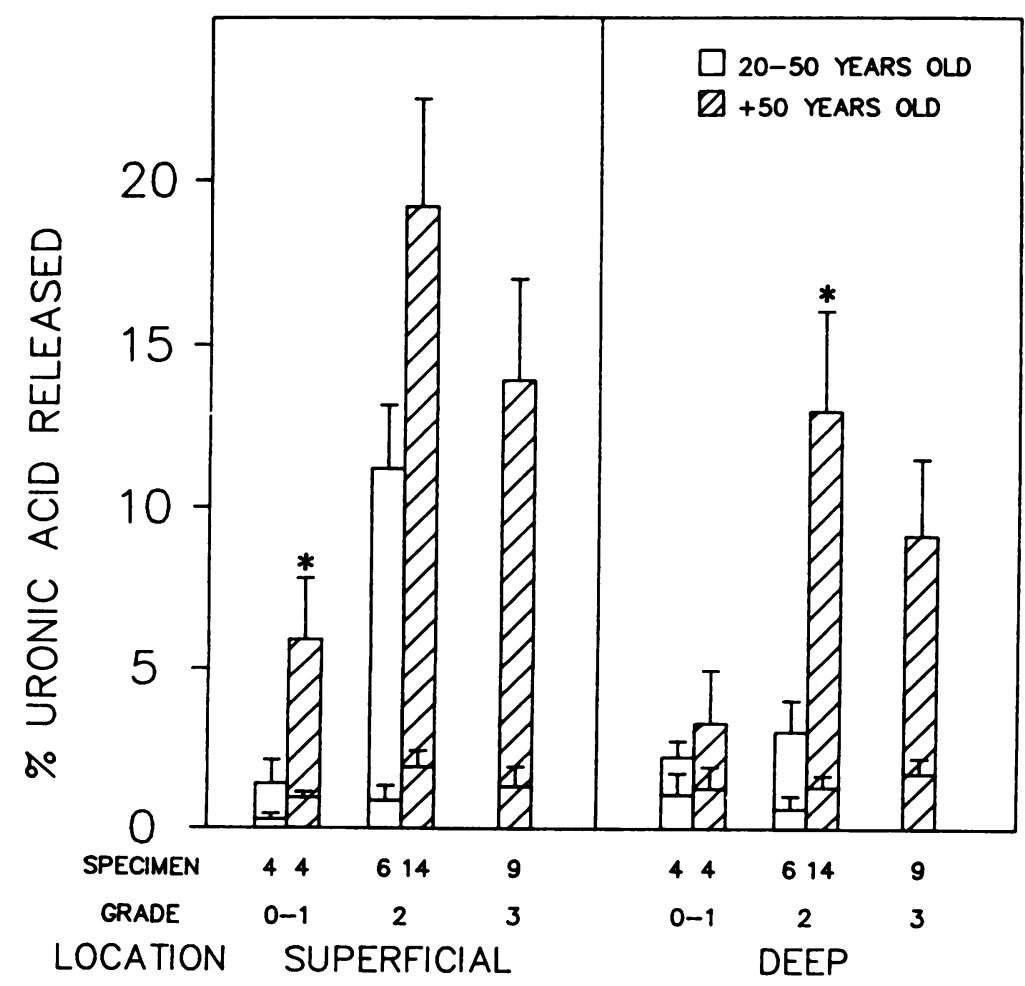

Fig. 5 Neutral metallo- $\mathrm{Pg}$ degrading enzyme activity in human articular cartilage: correlation in superficial and deep zones of the cartilage with aging. The total enzyme activity reached statistical significance in the superficial layer for grade $0-1$ specimens $(p<0.04)$ and in the deep zone for grade 2 specimens $(p<0 \cdot 05)$. 
activity increased in both zones with increasing age, regardless of lesion severity. This activity was consistently higher in thè older specimens. Statistically significant increases were noted in the superficial layer of grade $0-1$ specimens $(p<0.04)$ and in the deep zone for grade 2 specimens $(p<0 \cdot 05)$. As noted above (Figs 1 and 3 ), grade 3 specimens showed a decreased level of enzyme in both zones compared with grade 2 specimens. In both zones the active form of the enzyme showed slightly more activity in the oldest age group than in the youngest.

When divided according to the degree of degenerative changes, the younger (group 1) grade 0-1 specimens showed approximately the same distribution of enzyme activity throughout the cartilage depth. In the older (group 2) specimens, however, increased enzyme activity was shown in the superficial layer. In grade 2 specimens the highest level of total enzyme activity was noted in the superficial layer. In the deeper zone increased enzyme activity was found only in the older age group. The total enzyme activity distribution from the superficial layer of the younger age group, graded 2, when compared with the deep zone, was significantly different $(p<0 \cdot 004)$. In a similar pattern to that noted above a diminishing enzyme level was observed in grade 3 cartilage, for both superficial and deep zones, when compared with grade 2 cartilage.

\section{Discussion}

The extracellular matrix plays a crucial part in maintaining the viability of human articular cartilage. This viability may be compromised by changes that occur with age. The equilibrium within normal cartilage is thought to be due to a balance of the degradation and synthesis of matrix components. Thus degradation is under the double control of enzyme synthesis/activation and endogenous enzyme inhibitors. At present, little is known about the events that initiate these changes.

Neutral proteases are the most likely candidates for initiating cartilage degradation. These enzymes are activated at the physiological $\mathrm{pH}$ of the extracellular matrix. Our results suggest that the collagenolytic and Pg-degrading enzymes are closely associated with the appearance and progression of the alterations found in aging cartilage. Although it was evident that the two neutral metalloproteases studied were involved, the Pg-degrading enzymes appeared to have a more dominant role.

Increased neutral metalloprotease activity accompanied the development of cartilage fibrillation. Indeed, enhanced total Pg-degrading and collagenolytic activities reached a maximum level in grade 2 specimens. In addition, the active form of the Pg-degrading enzyme from older ( $>50$ years) grade. 2 specimens had significantly increased activit\& compared with grade $0-1$ specimens. These obse里 vations are consistent with the decreased proteogly can subunit hydrodynamic size in aging cartilage ang the increased proportion of keratan sulphate rela tive to chondroitin sulphate in the core protein. ${ }^{4} 5 \frac{8}{8}$ It may also explain the presence of isolated binding hyaluronic acid regions and the prominence of the smallest link protein size found in aging tissue. ${ }^{23} \mathrm{O}$ the other hand, the increased collagenolytic activit ${ }^{\circ}$ associated with cartilage alterations supports the involvement of proteases in fragmenting the col$F_{B}$ lagen network, which is typical of fibrillate cartilage. ${ }^{1-3}$

Although the morphological changes of the carti⿱ lage in the tibial plateau are focal, the metabolic and cellular processes appear to be generalised. The increased proteolytic activity in the cartilage was not exclusively related to the amount of load bearing to which the tissue was subjected. Enhanced levels of both collagenolytic and Pg-degrading enzymes wereo demonstrated, not only in the weight bearing area but throughout the entire cartilage. Indeed, significantly higher level of the Pg-degrading ens zyme was found in specimens from the non-weigh bearing area than in those from the weight bearino area. Although the exact meaning of this difference is unclear, it is possible that even if the cellula $\overrightarrow{\vec{S}}$ metabolism of all chondrocytes is altered, those from the non-weight bearing area may be subjecte to less damage than those from the weight bearing area. The appearance of lesions mainly in the weigh bearing area could be the result of a combination of increased enzyme levels and mechanical factors. $\mathrm{B}$ acting together, these two factors could produce significant change in the physicochemical properties of the cartilage.

Patients with progressive degeneration of theid cartilage also have cellular metabolic abnormalities These abnormalities cause the chondrocytes $t \frac{5}{2}$. synthesise and release increased amounts of pros teolytic enzymes. This phenomenon, recently ré ported by Nojima et al, ${ }^{24}$ could also apply to age related cartilage changes. From our study it was impossible to determine whether the macroscopis grading of cartilage represented chondrocytic metæ bolic alterations or more progressive changes in the matrix.

Although it remains to be determined whether th increased enzyme levels follow or precede tho appearance of lesions, the dynamics of the change 8 taking place in the cartilagenous tissue are reflectec $\mathbb{B}$ at least in part, by the variation in enzyme activity 迎 the different cartilage zones. Our data may give 
some insight into the time sequence involved for the development of lesions. Thus specimens graded $0-1$ showed low levels of Pg-degrading enzymes in both superficial and deep zones. As the lesions progressed, the enzyme activity increased. This was first noted in the superficial zone, suggesting that the chondrocytes of this layer are the first to be affected. The chondrocytic change could cause an increased enzyme level in the matrix. After the enzyme activity at the superficial layer was increased there was a subsequent increase of enzyme levels in the deep zone. This phenomenon, particularly noted in the grade 2 specimens of older subjects, may reflect the fact that once the superficial layer of cartilage has been altered the changes expose the chondrocytes of the deep zone of the cartilage to greater trauma. The evidence of cell multiplication and increased metabolic activity in the deep layer of fibrillated cartilage 2526 correlate well with the increased enzyme level found in this region. Of particular interest is the decline of Pg-degrading enzyme activity in both superficial and deep zones of grade 3 cartilage specimens. It is possible that once fibrillation penetrates the cartilage the repair process is compromised. In contrast, in younger individuals the chondrocytes may maintain a relatively normal metabolism, and thus the structure of the cartilage matrix may be less severely altered. This would explain our inability to find any specimens with severe degenerative changes (grade 3 classification) in the younger group.

We wish to thank Dr F Paquin, Head of the Department of Pathology, Notre Dame Hospital, for supplying the postmortem specimens. The authors are grateful to F Mineau and W Nedwetsky for their technical assistance. We also wish to thank W Nedwetsky and $F$ Lowry for revising the manuscript and $F$ Laberge for secretarial services. This work was supported by a grant from the Arthritis Society.

\section{References}

1 Silberberg R, Silberberg M, Vogel A, Wettstein W. Ultrastructure of articular cartilage of mice of various ages. Am J Anat 1961: 109: 251-76.

2 Weiss C. An ultrastructural study of aging human articular cartilage. J Bone Joint Surg /Am/ 1971; 53: 803-4.

3 Knight D P. Kempson G E. The relationship between the tensile properties of human articular cartilage and age. $J$ Bone Joint Surg /Br] 1981; 63: 641-2.

4 Inerot $S$, Heinegård $D$, Audell $L$, Olsson S E. Articular cartilage proteoglycans in aging and in osteoarthritis. Biochem J 1978; 169: 143-56.

5 Roughley P J, White R J. Age-related changes in the structure of the proteoglycan subunits from human articular cartilage. J Biol Chem 1980; 255: 217-24.

6 Mort J S, Poole A R, Roughley P J. Age-related changes in the structure of proteoglycan link proteins present in normal human articular cartilage. Biochem J 1983; 214: 269-72.

7 Plass A H K, Sandy J D. Age-related decrease in the link stability of proteoglycan aggregates formed by articular chondrocytes. Biochem J 1984; 220: 337-40.
8 Bayliss M T, Ali S Y. Age-related changes in the composition and structure of human articular cartilage proteoglycans. Biochem J 1978; 176: 683-93.

9 Roughley P J, White R J, Santer V. Comparison of proteoglycans extracted from high and low weight-bearing human articular cartilage with particular reference to sialic acid content. J Biol Chem 1981; 256: 12699-704.

10 Venn M F. Variation of chemical composition with age in human femoral head cartilage. Ann Rheum Dis 1978; 37: 168-74.

11 Jones I L, Lemperg R. The glycosaminoglycans of human articular cartilage. Molecular weight distribution of chondroitin sulfate in different layers in the adult individual. Clin Orthop 1978; 13: 364-70.

12 Mort J S, Campbell I K, Roughley P J. The mechanism of proteoglycan change pertaining to proteoglycan subunit and link protein heterogeneity in normal human articular cartilage [Abstract]. Trans Orthop Res Soc 1986; 11: 257.

13 Roughley P J. Poole A R. Campbell I K, Mort J S. The proteolytic generation of hyaluronic acid-binding regions derived from the proteoglycans of human articular cartilage as a consequence of ageing. [Abstract]. Trans Orthop Res Soc 1986: 11: 209.

14 Pelletier J P, Martel-Pelletier J, Howell D S, GhandurMnaymneh L, Enis E E, Woessner J F Jr. Collagenase and collagenolytic activity in human osteoarthritic cartilage. Arthritis Rheum 1983; 26: 63-8.

15 Martel-Pelletier J, Pelletier J P, Cloutier J M, Howell D S, Ghandur-Mnaymneh L, Woessner J F Jr. Neutral proteases capable of proteoglycan digesting activity in osteoarthritic and normal human articular cartilage. Arthritis Rheum 1984; 27: 305-12.,

16 Pelletier J P, Martel-Pelletier J, Altman R D, GhandurMnaymneh L, Howell D S, Woessner J F Jr. Collagenolytic activity and collagen matrix breakdown of the articular cartilage in the Pond-Nuki dog model of osteoarthritis. Arthritis Rheum 1983; 26: 866-74.

17 Pelletier J P, Martel-Pelletier J. Cartilage degradation by neutral proteoglycanases in experimental osteoarthritis. Arthritis Rheum 1985; 28: 1393-401.

18 Martel-Pelletier J, Pelletier J P. Degradative changes in human articular cartilage induced by chemotherapeutic agents. J Rheumatol 1986; 13: 164-74.

19 Meachim G. Light microscopy of Indian ink preparations of fibrillated cartilage. Ann Rheum Dis 1972; 31: 457-64.

20 Woessner J F Jr. The determination of hydroxyproline in tissue and protein samples containing small proportions of this amino acid. Arch Biochem Biophys 1961; 93: 440-7.

21 Santer V, White R J, Roughley P J. Proteoglycans from normal and degenerate cartilage of the adult human tibial plateau. Arthritis Rheum 1981; 24: 691-700.

22 Muir H, Bullough P, Maroudas A. The distribution of collagen in human articular cartilage with some of its physiological implication. J Bone Joint Surg [Br/ 1970; 52: 554-63.

23 Roughley P J, White R J, Poole A R. Identification of a hyaluronic acid-binding protein that interferes with the preparation of high buoyancy density aggregates from adult human articular cartilage. Biochem $J$ 1985; 231: 129-38.

24 Nojima I T, Towle C A, Mankin H J, Treadwell B V. Secretion of higher levels of active proteoglycanases from human osteoarthritic chondrocytes. Arthritis Rheum 1986; 29: 292-5.

25 Collins D H. McElligott T F. Sulphate $\left({ }^{35} \mathrm{SO}_{4}\right)$ uptake by chondrocytes in relation to histological changes in osteoarthritic human cartilage. Ann Rheum Dis 1960; 19: 318-30.

26 Mankin H J, Lippiello L. Biochemical and metabolic abnormalities in articular cartilage from osteo-arthritic human hips. $J$ Bone Joint Surg [Am] 1970; 52: 424-34. 